\title{
Analysis Application of Full Day School at Junior High School Kawangkoan City, North Sulawesi, Indonesia
}

\author{
Astika Junike Rambitan $\quad$ B. Binilang Treesje K. Londa \\ Magister Education Management Postgraduate Program, Manado State University, Indonesia
}

\begin{abstract}
Absract
The purpose of this research are to describe the following: 1. Application of the full day school system; 2 . Supporting factors for the application of full day school system; 3 . The obstacles for the application of full day school system; 4. The efforts for handling the obstacles in applying full day school system. The research method for this study is descriptive with the qualitative approach, and using the observation, interviews and documentation as the data gathering techniques, whereas tringulation method are used for the validation test within this research. The conclusion of this research are: 1 . The application of full day school system in 1st Junior High School State Kawangkoan have already been seriously applied by the Headmaster, yet the result don't actually came up according to the expectation. The values that are expected to be embedded within the students doesn't actually occurred. The full day school system supposed to encourage the development of learning by process yet in contrary the school only became result oriented. 2. Supporting factors for the application of full day school system. (a) $70 \%$ of the educators already became instructors. (b) the curriculum should focus on using active, creative, and attractive learning methods. (c) The headmaster's school management is considered good. (d) some of the school's facilities have been fixed and improved. 3. The obstacles for the application of full day school system: (a) the lack of stakeholder's knowledge about the full day school system. (b) most of the school's facilities are not adequate enough to support the full day school system. (c) The insufficient quality and capability of the educators in managing the classes, and most of the teachers are not prepared with the full day school system so they choosed the common rigid learning method. (d) the slow distribution of the fund from the superior sometimes became obstacles in procuring the tools and facilities which has been planned beforehand.4. The efforts for handling the obstacles in applying full day school system. (a) organising the socialisation for the stake holders for example while in the process of handling the school report card and not just the stake holders but also with the society so that there can be one comprehension about the full day school system. (b) to increase the professionalism of the headmaster in prioritizing the using of the school funds so that it can be delivered equally in fullfilliing the school's demand of facilities. (c) making a coordination with the superior about the distribution of the funds which often late and to anticipate the school's needs the School management can submit proposals to the successful alumni that can provide money to support the school's program. (d) to improve the quality of the teachers so that the students can do learning activities without the feeling of boringness. Suggestions: 1 . The application should be implemented step by step while focusing in designing the curriculum to implement the full day school system. Taking examples to what applied on the schools in developed country is important. While measuring the readiness of the school should be done first. 2 . The headmaster should maintain the the good managerial aspects while keep watching the management of the facilities. 3. School should arrange meeting with the stake holders and to promote to the society while first completing the school facilities in concern of the student's comfortnes. 4. The teachers must improve their quality and motivation to do what best for the students in applying the full day school system.
\end{abstract}

Keywords : Full Day School System

DOI: $10.7176 / \mathrm{JEP} / 10-17-01$

Publication date: June $30^{\text {th }} 2019$

\section{Introduction}

Education is one vehicle for forming the character of the nation, and school is an important location where education actors carry out their duties both as educators and as students. In Law No. 20 of 2003 article 1 concerning the national education system that education is a conscious and planned effort to create a learning atmosphere and learning process so that students actively develop their potential to have religious spiritual strength, self-control, personality, intelligence, noble character, and skills that needed himself, society, nation and country.Developing abilities and forming dignified national character and civilization in order to educate the nation's life so that the potential development of students becomes faithful and devoted to God Almighty, noble, healthy, knowledgeable, capable, creative, independent, and a citizen democratic and responsible is the purpose of education as stated in Law No. 20 of 2003, Article 3. Education carries the task of producing a good generation of people who have values and norms in their lives. To achieve this goal, education requires a system as a whole that is integrated from a number of components that interact with each other and carry out certain functions in order to make students fit the stated goals.

Muhadjir Effendy, Minister of Education and Culture of the Republic of Indonesia explained the policy 
background of Fullday School during a gathering at the Muhammadiyah Central Executive Yogyakarta. He explained that the Full Day School System was present to realize the Presidential Nawacita No. 8 which was revealed in the Character Education Strengthening (PPK) program and the educational objectives above. In other words, the addition of school hours is expected to increase Character Strengthening (PPK) as an implementation of the Ministry of Education and Culture (Kemendikbud) policy, not only having strong character but also being able to innovate, be productive, and actively participate in learning activities. Compared to the education system in Finland students are only given 4-5 hours to study at school with little homework. The short hours of learning are actually considered to encourage them to be more productive. These government efforts certainly have a good goal for education in Indonesia, in other words education is able to produce quality and competitive output. But it is also a big challenge for the world of education in carrying out the rules of the new study hours because in fact Full Day School stole many children's rights during the period of their growth who also need adequate rest, time to play, time to adapt to the surrounding environment through activities social in the community and developing themselves through the activities they like have been absorbed by the time to study at school. Continuous learning will only be centered on academic activities and requires a prolonged high mentality. The impact makes children tired, emotions disturbed, attention to concentration is lacking, and a lot of physical fatigue, such as frequent dizziness, body aches, abdominal pain. Children in school age are still in the stage of growing and developing so that not only learning, children need to play and interact with the environment outside of school. By playing not only causes pleasure, and reduces negative energy so it reduces stress but playing activities and interacting with the wider environment becomes a means for children to develop themselves optimally in their growth and development (Djaali, 2008).

Kawangkoan 1 Public Middle School is one of the junior high schools in the North Kawangkoan region, Minahasa District, which is implementing a Full Day School system and has been going on for three years. Based on the results of interviews conducted by researchers to several students, many complained about the lessons being too long with breaks for very short breaks, so students easily became bored especially at the last lesson when the day had already begun in the afternoon and the stamina of students began to decline causing student concentration to the lessons given by the teacher to be reduced. According to some students who were interviewed by Full Day School made them no longer have time to attend church activities and the community because they came home from school late in the evening with their tired bodies having to do homework so time to rest, play and socializing with the community is reduced, and incomplete school facilities greatly affect their comfort in being in school for a long time.This situation makes some students lazy to go to school and there are even some students who skip or go to canteen during class hours. Based on this background, there is a gap between the expectation of the implementation of a full day school system and the reality that occurs in the field. In connection with this, the writer wants to do research with the title "Implementation of the Full Day School System in Kawangkoan Junior High School".

\section{Literature Review}

\subsection{Definition and Purpose of Full Day School Learning}

The day-to-day school program (full day school) is an educational program where all activities are in school throughout the day from morning to evening. In that sense, the meaning throughout the day is essentially not just an effort to increase time and increase learning material, but full day school is intended to improve the achievement of education and learning goals with the addition of lessons so students are able to explore a subject with a proportional time for a full day. (Ragella, 2011: 43). Full day school is one of the clever works of thinkers and practitioners of education to deal with the lack of parental control of children outside formal school hours so that schools that are initially held 5 to 6 hours change to 8 to even 9 hours. (Susanti and Asyhar: 2015)In Permendikbud No. 23 of 2017 concerning School Day which regulates full day school contained in article 2 paragraphs 1,2,3 and 4 where it is stated that school days are held 8 hours in 1 day or 40 hours for 5 days in 1 week. The provisions in paragraph 1 include the rest period of 0.5 hours in 1 day or 2.5 hours for 5 days.

Full day school according to Sukur Basuki (2014) is a school that is partially used for learning programs in an informal atmosphere, not me, fun for students and requires creativity and innovation from the teacher. In this case Sukur refers to a study which states that affective learning time for children is only 3-4 hours a day (in a formal setting) and 7-8 hours a day (in an informal setting). Schools with a full day school system contain more learning with an informal atmosphere (www.strkNllmj.sch.id, 09/22/2018). Whereas according to Mujayanah (2013: 13) full day school is an alternative education model, where students are in full-day school at the learning process and worship process. The learning process in a full day school system is not only formal, but there are many learning environments that are informal and not rigid and fun for students. Hilalah (2009: 22) argues that full day school is a learning process that is carried out in a full day that applies the basis of integrated curriculum and integrated activity which means that almost all children's activities are in school, ranging from learning, eating, playing, and worshiping in education World. Full day school emphasizes components that are arranged regularly and well to support the process of maturing humans (students) through teaching and training efforts 
with a longer or longer time in school compared to schools in general based on the concept of integrated curriculum and integrated activity. Thus, a full day school system is a component that is arranged regularly and well to shape the character of students, improve achievement, use time with quality activities in schools and support the process of human maturation (students) through teaching and training with time in schools that are longer or longer than schools in general.

Full Day School was present to realize the President's Nawacita No. 8 namely "Revolutionizing the nation's character through a policy of restructuring the national education curriculum by prioritizing aspects of citizenship education, which places proportionally the aspects of education, such as teaching the history of nation formation, patriotism values and the love of the country, the spirit of defending the country and character in Indonesian education curriculum "which is derived from the Character Education Strengthening (PPK) program and educational goals.Full day school implementation is an alternative to overcome various problems of education, both in achievement and in terms of morals or morals. By participating in full day school, parents can prevent and neutralize the possibility of children's activities that fall into negative activities. One of the reasons parents choose and enter their children to full day school is in terms of student education. Many reasons why full day school is a choice (Ragella 2011: 50)

First, the increasing number of parent careers who give less attention to their children, especially those related to children's activities after returning home from school. Second, socio-cultural changes that occur in the community, from agrarian societies to industrial societies. These changes clearly affect the mindset and perspective of society. The progress of science and technology is so rapid development, especially communication technology and information on urban living environment that leads to individualism. Third, socio-cultural changes affect the mindset and perspective of society. One characteristic of industrial society is measuring success with material. This is very influential on the pattern of life of the community which ultimately has an impact on changing roles. The role of the mother who used to only be a housewife, with her main task of educating children, began to shift. The role of mothers in the present is not only limited to being a housewife, but a mother is also required to be able to pursue a career outside the home. Fourth, the progress of science and technology is so fast that if it is not examined, we will become victims, especially victims of communication technology. With the increasingly sophisticated developments in the world of communication, the world seems to be borderless world, with many television programs and the proliferation of television stations making children more enjoy sitting in front of the television and playing play stations (PS). The existence of the changes above is an important signal to find an alternative solution. From such conditions, education practitioners finally think hard to formulate a new paradigm in the world of education.

In addition to aiming at developing quality education, Full Day School is the main full day school aiming as an effort to shape student character and instill positive values in students. Full day school also provides a strong foundation in learning in all aspects, namely intellectual, physical, social and emotional development. As said by Aep Saifuddin that a full day school school can be more intensive and optimal in providing education to children, especially in the formation of morals and creeds. Then according to Farida Isnawati said that time is to educate students more so that it is not just a theory, but practice getting more time proportions. So that education is not only a minded theory but an application of science (Seli 2009: 23)

\subsection{Factors Supporting and Inhibiting Full Day School}

Baharudin (2009: 232) every learning system must have advantages (supporting factors) and weaknesses (inhibiting factors) in its implementation, including the full day school system. The supporting factors and inhibitors of the full day school system are as follows:

1. Supporting Factors for Implementing the Full Day School SystemThe factor supporting the implementation of the full day school system is that each school has goals to be achieved, of course at the institutional level. To get to that direction various fittings are needed in various shapes and types. Among the supporting factors include curriculum, education management, facilities and infrastructure, learning facilities, and the most important thing in education is human resources (HR).

2. Factor Blocking Full Day SchoolOne of the factors that inhibited full Day School was facilities and infrastructure. Facilities and infrastructure are part of education that is very very vital, in order to support the success of education. Therefore, there is a need for good management of education, as said that schools can succeed if the management of facilities and infrastructure is also good. In addition, the full day school inhibiting factor can also be caused by the teacher, whether the teacher at the school that is implementing full day school can utilize the given time well or vice versa.

\subsection{Advantages and weaknesses of a Full Day School}

Full day school system implementation has many benefits for students, for example in academic aspects. Learning time is also one of the dimensions of a child's experience. According to Hasan (2006: 114) that the existence of a full day school system shows children will learn more than play, because there is time involved in 
class, this results in high productivity of children, so it is also more likely to be close to the teacher, students also show a more positive attitude, because there is no free time to do deviations because all day students are in class and are under the supervision of the teacher.Full day school system as stated by Hasan (2006: 114) has the advantages of:

1) A full day school system is more likely to make education complete. Benyamin S. Bloom stated that the objective (objectivity) of education includes three fields, namely cognitive, affective and psychomotor.

2) The full day scholarly system is more likely to realize the intensification and effectiveness of the educational process. Full Day School with a centralized dormitory pattern and 24-hour supervision system is very possible for the realization of an intensification of the educational process in the sense that younger students are directed and formed according to the mission and orientation of the institution concerned, because the activities of younger students are monitored because they have been directed from the start.

3) A full day school system is an institution that has proven effective in applying students' abilities in everything, such as those that cover all areas of cognitive, affective and psychomotor and also foreign language abilities.

However, Hasan (2006: 115) suggests that this full day school system is inseparable from shortcomings or weaknesses, including:

1) full day school system often creates boredom in students. A full day school learning system requires good physical, psychological and intellectual readiness. The tight schedule of learning activities and the application of consistent sanctions within certain limits will cause students to become bored. But for those who are ready, this is not a problem, but it will bring a special preoccupation, therefore carefulness and improvisation of management in this case is very much needed. Expertise in designing full day school is not boring.

2) Full day school system requires attention and seriousness of management for managers, so that the learning process at a full day school patterned educational institution takes place optimally, attention and outpouring of thought is needed, especially from its management, even sacrifice both physical, psychological, material and others. Without this, full day school will not achieve optimal results and may even be a meaningless routine.Full day school system implementation is expected to make students obtain general education that is anticipatory towards the development of science and technology. Children's potential is channeled through extracurricular activities, the development of anticipated children's interests and intelligence from an early age through psychological monitoring.

\subsection{Character building}

William \& Schnaps defines character education as "Any deliberate approach which school personnel, often in conjunction with parents and community members, help children and youth become caring, principled and responsibled". The meaning of character education is a variety of efforts carried out by school personnel, even those carried out jointly with parents and community members, to help children and adolescents become caring, opinionated, and responsible. Whereas according to Creasy defines character education as an effort to encourage students to grow and develop with competency in thinking and cling to moral principles in their lives and have the courage to do 'right', even though faced with various challenges (Zubaedi, 2012: 102).

Character education in detail has five objectives. First, develop potential heart / conscience / affective students as human beings and citizens who have national character values. Second, develop the habits and behavior of students who are commendable and in line with universal values and religious cultural traditions. Third, instill leadership and responsibility of students as the next generation of the nation. Fourth, develop the ability of students to be independent, creative and nationally minded human beings. Fifth, develop a school life environment as a safe, honest, creative and friendship learning environment, and with a sense of nationality that is high and full of strength (dignity).

Ratna Megawangi, in Asmani (2011: 147) exemplifies China's success in implementing character education since the early 1980s. According to him, character education is to carve morals through the process of knowing good, loving the good, and acting the good (an educational process that involves cognitive, emotional, and physical aspects so that it is noble). Character education is an urgent need considering that demoralization and degradation of knowledge have so infectiously infected this nation in all walks of life. Character education is expected to be able to raise awareness of the nation to build a solid national foundation.

The value developed in character education in Indonesia comes from 4 sources, namely: First, religion. Indonesian society is a religious society. Therefore, his life is always based on the teachings of his religion and beliefs. Politically, state life is based on values derived from religion. Therefore, the value of character education must be based on rules derived from religion. Second, Pancasila. The values contained in the Pancasila become values that govern political, legal, economic, social, cultural and artistic life. Character education with Pancasila values to be able to apply the values contained in Pancasila in their lives as citizens. Third, culture. Cultural values are used as a basis in giving meaning to a concept and meaning in communication between members of the community. Fourth, national education goals. The national education objectives contain various human values that must be possessed by every Indonesian citizen. This national education goal is the most operational 
in developing national culture and character (Zubaedi, 2012: 143).

Based on the grand design developed by Mone (2010), psychologically and socio-cultural character formation in individuals is a function of all human potential (cognitive, affective, conative, and psychomotor) in the context of cultural social interactions (in family, school, and society ) and lasts for life. According to Zubaedi (2012: 93) character configurations in the context of the totality of psychological and socio-cultural processes can be grouped in; heart (spiritual and emotional development), intellectual development, sports and physics, and the feeling of affection and creativity.

Dharma Kesuma (2011: 09) states that the goals of character education are divided into three, namely:1) Facilitating the strengthening and development of certain values so that they are realized in children's behavior, both during the school process and after the school process (after graduating from school)2) Correcting student behavior that does not correspond to the values developed by the school3) Building harmonious connections with family and society in acting out the responsibilities of character education together. Whereas the character education objectives contained in the Character Education Implementation Guide (2011: 07) by the Ministry of National Education, states that character education aims to develop values that shape the nation's character, namely Pancasila, including: 1) developing the potential of students to become good-hearted human beings , good minded and well behaved; 2) building a nation characterized by Pancasila; 3) developing the potential of citizens to have an attitude of self-confidence, pride in their nation and country, and to love humanity.Based on the opinions of experts, it is shown that character education in Indonesia is directed at making the Pancasila as the basis of Indonesian people for the state and loving the homeland and loving their fellow humans. This was revealed by Heri Gunawan (2012: 30) which states that character education is essentially aimed at forming a strong, competitive, noble, moral, tolerant, collaborative, patriotic spirit, dynamic developing, science and technology oriented which all inspired by faith and piety to God Almighty based on Pancasila.

\section{Research Method}

The approach and research method used by researchers in this study is a qualitative research approach with descriptive analysis method. According to Indrawan and Yaniawati (2014: 133) that the qualitative research approach is determined by the extent to which researchers collect data on the object of research through observation, in-depth interviews and documentation studies which are the main basis of researchers in describing data comprehensively and presenting it more contextually focused according to the reality in the subject real research.

This research was conducted at Kawangkoan 1 Junior High School, North Kawangkoan District, Minahasa Regency, North Sulawesi Province. Located in central kawangkoan with a beautiful school environment and school achievements that are not small either at the district or national level and school facilities that are superior to the schools in the Kawangkoan region make the Kawangkoan 1 Public Middle School as a school that is popular with the public. From PPDB, the number of applicants exceeds capacity capacity, Public Middle School is one of the referral schools in Minahasa District and is implementing a Full Day School system. The research time is held in January 2019.

In this research which is the instrument of research is the researcher himself (Nasution, 2003: 55) Therefore the researcher is present in the field collecting a variety of data in different situations, paying attention, feeling, understanding, analyzing and making conclusions on the collected data and making results reports research. The data source that became the main informant in this study was the school community including: (1) the principal, (2) the vice principal, (3) educators, (4) education, (5) parents, and (6) students . The research data is obtained through two data sources, namely:

1. Primary Data. Primary data is data obtained directly from the results of interviews with informants or informants who are considered potentially in providing relevant and actual information in the field

2. Secondary DataSecondary data is supporting data for primary data such as literature literature, relevant research, documents, observations, and data taken from various sources that are relevant to research in the field.

In general in qualitative research methods, researchers rely on the results of their research through participatory observation or observation, interviews, and documentation studies to gather word (text) or photographic data (Indrawan and Yaniawati, 2014: 144). To collect primary data, the following techniques are used:

1. Observation Technique. Observation was carried out as an effort for researchers to collect data and information on primary data sources by optimizing the observations of researchers. Observation is carried out by using several stages in observation research, namely focused observation and selected observation (Sedarmayanti 2011: 77);a. Focused ObservationThe researcher conducts taxonomic analysis so that he can find focus, the researcher then generates conclusions.b. Selected ObservationResearchers have found characteristics of contrasts or differences and similarities between categories, and found relationships between one category and another.

2. Interview Technique. Interviews used in data collection of this research are in-depth (indeep interview). Interviews conducted by researchers to obtain information data is an unstructured interview where the 
interviewer makes a relaxed atmosphere but can not be separated to be able to capture the meaning or symbol of the content of the conversation (Sedarmayanti, 2011: 82). The interviewer conducts a question and answer session with the research subject using a tool called the interview guide (attached). In order for interviews to take place more effectively and efficiently, the researchers use cameras and notebooks to get accurate results.

3. Documentation Study Techniques. Documentation studies used to obtain data and information in the form of notes, authentic evidence and images related to the problem under study.

The data analysis technique used in this study is the Milles and Huberman model found in Sugiyono (2012: 245 ) in processing qualitative data through the stages of reduction, data presentation, and conclusion.

1. ReductionReducing means summarizing, choosing the main and important things and then looking for themes and patterns (Sugiyono, 2012: 247). At this stage the researcher sorts out which information is relevant (information that has a connection and is closely related to the subject matter being studied) and which is not relevant to the research. After the data has been reduced cone, the fewer and more leads to the core of the problem so as to provide a clearer picture of the object of research.

2. Presentation of DataThe next step after data reduction is to present data. Data presented in the form of tables and descriptions of descriptive explanations.

3. Withdrawal ConclusionThe final stage of data processing is drawing conclusions. After all the data presented problems that become the object of research can be understood and then conclusions will be drawn which are the results of this study.

\section{Result And Discussion}

4.1. Application of Full Day School System at Kawangkoan Junior High School.

The findings of this study indicate that the application of a full day school system at Kawangkoan 1 Junior High School has not strengthened the character education of students at school. Judging from its application, it has not fully fulfilled the indicators of character education. This can be seen from the behavior of some students who are still skipping during class hours, less polite and polite towards teachers and fellow students and the response of students who do not fully enjoy long learning time at school because the learning methods and strategies used by some teachers are less attractive, but this is also influenced by the limitations of school facilities and facilities that are incomplete and uncomfortable with long hours of study at school.The regulation that became the basis for the implementation of the FDS system was Permendikbud No. 23 of 2017 concerning five school days (Permendikbud FDS).

The philosophical consideration of the Minister of Education and Culture's FDS is the restoration of character education. The character education restoration was fulfilled through the addition of school time, so that school operations were completed in the afternoon. (Regulation of the Minister of Education and Culture Number 23 of 2017). In other words, through the implementation of the FDS system there is a change in character for students. But if what happens is only the longer learning time without being followed by changes in student character, it can be said that the application of the FDS system does not provide a contribution in strengthening student character education. Based on the above information, it shows that the implementation of a full day school system in Kawangkoan 1 Junior High School is not optimal.

Viewed from a theoretical perspective, teaching and learning activities in a full day school system are carried out attractively and supported by adequate infrastructure so that students are motivated to explore and explore learning material and more easily understand without experiencing boredom. This statement is in line with the opinion of Sukur Basuki (2014), namely:Fullday school is a school that is partially used for learning programs with an informal atmosphere, not rigid, fun for students and requires creativity and innovation from the teacher.In the application of a full day school system, the components are arranged regularly and well to support the process of human maturation (students) as well as strengthening the character education of students through teaching and training efforts with longer time in school, so that strengthening character education is embedded in self students.

The importance of Creasy's character education:Character education is an effort to encourage students to grow and develop with thinking competencies and cling to moral principles in their lives and have the courage to do what is right, even though they are faced with various challenges (Zubaedi, 2012: 102). Further according to William \& Schnaps:Character education is a variety of efforts carried out by school personnel, even those carried out jointly with parents and community members, to help children and adolescents become caring, opinionated, and responsible.The purpose of implementing the full day school system is to realize the President's Nawacita No. 8 namely "Revolutionizing the nation's character through a policy of restructuring the national education curriculum by prioritizing aspects of citizenship education, which places proportionally the aspects of education, such as teaching the history of nation formation, patriotism values and the love of the country, the spirit of defending the country and character in Indonesian education curriculum "which is derived from the Character Education Strengthening (PPK) program and educational goals.Full day school implementation is an alternative to overcome various problems of education, both in achievement and in terms of morals or morals. 
By participating in full day school, parents can prevent and neutralize the possibility of child activities that fall into negative activities such as tauran, free association, drugs, wild racing, and other harmful activities as often done by most students. Through this program bad activities can be minimized and students are directed to get used to the activities of developing academic potential in schools. One reason also parents choose and enter their children to full day school is in terms of student education, with school learning habits with a longer time, students will be accustomed to the stage of thinking that continues to make students smart, creative and accomplished.Based on the descriptions above, it can be said that with the implementation of an optimal full day school system and carried out maximally accompanied by supporting school infrastructure, it will make students eager to take part in learning in school, comfortable while in the school environment, reducing boredom due to long study hours and teachers are free to create and innovate in teaching because they are supported by school facilities so that goals can be achieved as expected.

Thus it can be concluded that the application of a full day school system can improve student and school performance, educate students in habituation to good behavior by planting character values in every teaching and learning activity meeting, and with this program students avoid activities outside of school harmful. This can be realized to the maximum if the quality and quantity of teaching / education staff and schools are in accordance with the standards for implementing a full day school system starting from school facilities that support complete facilities and infrastructure, comfortable and attractive classes, creative and innovative teachers in continuing teaching developed so that it can produce a pleasant learning atmosphere that stimulates students to think critically and be creative and enjoy quality learning.

\subsection{Supporting Factors for Implementing the Full Day School System at Kawangkoan Junior High School.}

The results showed that the factors supporting the implementation of a full day school system in Kawangkoan 1Junior High School, including SMP Negeri 1 Kawangkoan, had teachers who $70 \%$ of them were instructor teachers. The quality and quantity of schools in which there are quality and quantity of human resources which are important in achieving the goal of implementing a full day school system, namely Strengthening Character Education and producing quality human beings both in terms of academic, skill and character, because qualified teachers will produce quality students also with the teaching and treatment of teachers towards students and in its implementation the teachers also really need to be supported by adequate facilities and infrastructure.

On the other hand, the supporting factor for the full day school system in Kawangkoan 1 Junior High School is the curriculum used by the school, the 2013 curriculum, where the full day school program is the result of the development of the 2013 curriculum. , and refer to the learning process that uses learning methods and interesting learning styles such as discussion, playing and teaching students to dare to appear. The contents of the curriculum are made in conjunction with the daily lives of students, where the curriculum integrates life skills in all learning materials. In this curriculum, children develop mutual respect, tolerance and ethics that are in line with the goal of implementing a full day school system that is emphasizing on strengthening the character education of students.

The professionalism of school principals in terms of school management / management is an important factor in the running of all school activities properly. Viewed from the planning, control of the teaching staff and education as well as the administrative and school environment that has been organized until supervision continues. School management is an important indicator in carrying out a full day school because a school principal who is good at managing schools will greatly impact the progress of the school and increase the quality and quantity of the school. Some school facilities and infrastructure that have just been rehabilitated such as computer laboratories, school lobbies, and the appearance of the front of the school also add to the comfort of all school residents.

If viewed from a theoretical perspective, the professionalism of school principals in terms of school management is one of the factors supporting the successful implementation of a full day school system. Supporting factors according to Baharudin (2009: 232). The factor supporting the implementation of the full day school system is that each school has goals to be achieved, of course at the institutional level. To get to that direction various fittings are needed in various shapes and types. Among the supporting factors include curriculum, education management, facilities and infrastructure, learning facilities, and the most important thing in education is human resources (HR). From the above opinion, it can be said that the supporting factors for the implementation of a full day school system are relevant curriculum and good school management by the principal, facilities and infrastructure that are fully supportive and adequate, and quality human resources.

The headmaster of SMP Negeri 1 in implementing the full day school system has carried out his duties as a manager at school well. Organized management of schools starting from planning, organizing, moving all components of the school in carrying out their respective duties in accordance with the main tasks and functions, and supervision of each of the affairs that exist. Facilities and infrastructure are also very important factors in supporting all school activities both in implementing a full day school system and in supporting other school activities. There are several parts of the school that have been renovated and computer labs that are increasingly 
complete.

However, there are still many school facilities and infrastructure that have not been touched by repairs or renovations, so that they need the attention of the principal in overcoming the problem. The $70 \%$ of teachers are instructors as other supporting factors that are no less important for improving the quality of students, especially in strengthening student character education in Kawangkaon 1 Public Middle School. Even though it has been called an instructor, it does not guarantee the quality of work of the teaching staff in implementing this full day school system.

The research findings show that the principal of Kawangkoan 1 Public Middle School in implementing a full day school system has implemented its maximum managerial function in planning, organizing, mobilizing and controlling the existing teaching staff, and also for the convenience of school residents and the achievement of adequate facilities and infrastructure has rehabilitated school toilets, held school lobbies and improved computer laboratory facilities. The quality of teachers is where $70 \%$ of the teachers are instructors and continue to improve their quality through training, MGMP, 2013 Curriculum training, and HOTS. This is a factor supporting the implementation of a full day school system in Kawangkoan 1 Junior High School.

\subsection{Inhibiting Factors for Implementing the Full Day School System in Kawangkoan Junior High School.}

The results showed that the inhibiting factors of the full day school system at SMP Negeri 1 Kawangkoan were a lack of understanding from several parents of students and stake holders regarding the implementation of a full day school system. Their response to this program is to only burden students and reduce time together with their families. Lack of understanding of the surrounding environment ignores the low level of community support for the implementation of this program, not a few parents who complain about long hours of study and tasks assigned to students. Principals as leaders in this school must continue to strive to provide understanding and socialization for the community, stakeholders and all parents of students and even the students themselves concerning the purpose of implementing this full day school system.

The similarity of understanding between the school and the surrounding environment will have a positive impact on the implementation of a full day school system in this school especially in terms of school promotion to the community. Education happens not only in schools, but also in families. Limited time with family is one of the problems in implementing this FDS. Education within the family can include things that cannot be reached by teachers at school, both inwardly and physically. Children also need quality time with their families.

Character education provides many things to do morally, ethically, and academically which are the main concern of families, communities and schools. Character education can not only be from school, but how students get character education in the family and community environment. (Abdurahman Ahmad, et al: 2011). Based on these opinions, the researchers concluded that children's character education is not necessarily in the school environment. Children also need to socialize with the community. Caring, respect and responsibility and other character values can occur in the home and community environment, just how the environment stimulates children to do and explore the values of these characters. The existing facilities and infrastructure are still incomplete, while this is very much needed in the implementation of this full day school system but also in other school activities that must be supported by adequate school facilities, for example a science laboratory with equipment inside has never been updated again, less comfortable and attractive classrooms, less complete sports and play facilities, unrepresentative libraries and uncomfortable school canteens.

A leader must be wise in looking at the shortcomings that exist at school, not just focusing on the appearance of the outside, but also concerning the comfort of students in the classroom and even supporting rooms in the form of laboratories, because learning will be more successful if students are involved both physically and physically. The principal in this case carries a great responsibility in making the availability of complete facilities and infrastructure so that the implementation of this full day school system can run to the maximum and as expected. Facilities and infrastructure are part of a very vital education, in order to support the success of education. Therefore, there is a need for efforts and management and policies of the principal to prioritize the needs of infrastructure, as said that the school can succeed if the management of facilities and infrastructure is also good. Often the late disbursement of funds from the center to the school becomes an obstacle to the realization of the school plan both in providing facilities that have been planned and in terms of meeting other school needs, it should encourage school principals to make maximum efforts to coordinate with superiors to be more timely in managing the budget distributed to each school.

In addition, the full day school inhibiting factor is also caused by the quality of the teacher, whether the teacher at the school that applies full day school can utilize the given time well or vice versa. Human resources in this case the teacher really determines the success of the implementation of a full day school system. Teachers who are lazy to innovate and develop their creativity are a big problem for schools, especially in implementing this system, because the strengthening of student character education mostly comes from teachers. As expressed by Aristotle in Heri Gunawan (2012: 23) that: Character is closely related to habits that are often manifested in behavior. 
Habits will form characters, characters will shape behavior. Also added according to Hoge that: Character education is a way to regulate students' behavior to become good citizens in the future. (Muhammaf Javed: 2009) Based on this opinion, it can be said that the teacher is an important factor in the success of character education for students at school. The things that are accustomed to teachers at school are what will manifest in the behavior of the students who are educated.Some of the teachers at Kawangkoan 1 Public Middle School while teaching in lessons during the afternoons where their stamina has diminished and are getting tired, sometimes preferring to use rigid and unattractive conventional learning, while at that time students also feel the same and desperately need the role of the teacher in stimulating students to stay motivated to take part in learning so that they must work hard in preparing and choosing learning methods in accordance with the conditions so that students do not feel bored.

The findings of this study indicate that the lack of understanding of stakeholders and the surrounding environment regarding the implementation of a full day school system at Kawangkoan 1 Junior High School made this school get a lot of bad comments about the implementation of this full day school system, and some parents felt that the quality of time with their children was reduced. Facilities and infrastructure that are not yet complete, such as comfortable canteens, representative libraries, adequate sports and play facilities and delays in disbursing funds from the government make it difficult for schools to prepare complete and comfortable facilities for students as well as educators. Learning hours that are too long make students and teachers easy to get tired and bored during the afternoon hours, resulting in the lack of preparation and lack of innovation of teachers in choosing methods and learning strategies for students, this is the obstacle to the implementation of a full day school system in Public Middle Schools 1 Kawangkoan.

\subsection{Efforts are being made to overcome obstacles to the implementation of a full day school system in Kawangkoan Junior High School}

The results showed that the lack of understanding of stakeholders regarding the implementation of a full day school system at SMP Negeri 1 Kawangkoan had an impact on the support for the implementation of a full day school system in this school. This of course will result in the promotion of schools in the community and the assumption of parents regarding the burden that their children must undergo while in school is so heavy. Communication between the school and the community must be done openly or transparently so that there is no misunderstanding or ignorance of the community regarding the program carried out by the school.In order for the full day school system in SMP Negeri 1 Kawangkoan to be supported by all existing stakeholders, the school should conduct socialization with all parties involved / interested in the school but also, to all existing communities so that there is no misunderstanding between the community and stakeholders on the implementation this full day school system.

From the previous explanation it can be said that schools need to guarantee the existing community and stakeholders with supporting school facilities as a whole because the facilities and infrastructure are very important in supporting the implementation of a full day school system. The availability of complete and comfortable facilities and infrastructure will greatly affect the mental and inner students while they are in school. When there is funding from the center that enters the principal, it must prioritize which ones must be repaired, equipped to support the full day school program. Renovation in places that really don't really matter is only spent on the given budget. Moreover, funds from superiors are often late or not on schedule, resulting in many school plans in terms of procurement of facilities and infrastructure to be delayed. The principal as a school manager must coordinate continuously with superiors regarding the issue of disbursing these funds, or look for other alternatives by giving proposals to parties deemed capable of supporting programs in this school.

The findings of this study indicate that, the professionalism of principals in managing funds for the procurement of facilities and infrastructure is very important for the availability of school facilities and infrastructure that support the implementation of this full day school system. Another important element in the implementation of a full day school system is the quality of the teachers. Even though the teacher is an instructor who can direct other teachers, but if the quality in the class is not optimal, students cannot capture the purpose of the learning. The teacher holds a very important role in achieving the goals of this education, when the teacher is unprepared, undoubtedly the teacher will tend to fill students' time only with routine activities which do not have a significant impact on improving the competency of students. It can be imagined if the school only provides long hours of study on the name of extracurricular without proper and serious guidance from the teachers.

Therefore improving the quality of teachers does not have to be continuously carried out continuously through training outside the school or training conducted internally in the school. The research findings show that with the socialization to the public and all stakeholders, they will change their mindset towards the implementation of a full day school system in Kawangkoan 1 Junior High School. In addition, by submitting requests for facilities and infrastructure assistance to certain parties, also coordination with superiors and with wise management of existing budgets is one of the efforts to overcome obstacles concerning infrastructure facilities in the future of the full day school system in the Public Middle School. 1 Kawangkoan. Improving the 
quality of teaching staff in carrying out teaching and learning activities will greatly help students in full day school programs at Kawangkoan 1 Junior High School.

\section{Conclussion}

Based on the results of research and discussion, the conclusion of the study is the application of a full day school system in Kawangkoan 1 Junior High School has actually been maximally pursued by the principal, but in reality it is still not as expected. Character values that are expected to be embedded in students have not yet fully materialized. A full day school system should support the development of process-based learning. However, schools only form results-oriented learning. Supporting factors for the implementation of a full day school system in Kawangkoan Public Middle School 1 can indeed be said to have exceeded other surrounding schools such as HR, several facilities that have been equipped but, the supporting factors are actually not enough to be used as a basis for implementing the Full day school system this. this is not in line with the inhibiting factors that the researchers found, namely in the form of several other facilities that were as important as the Science LAB, the Library had not been repaired and equipped. Thus, the efforts made by the school must continue to be maximized for the optimal implementation of the Full Day School system.

\section{References}

Abdurahman Ahmad, dkk. 2011. Pendidikan Seumur Hidup. Jakarta: Universitas Negeri Jakarta.

Asmani. 2011. Buku Panduan Internalisasi Pendidikan Karakter Di Sekolah. Jogjakarta: Diva press.

Baharuddin. 2009. Pendidikan \& Psikologi Perkembangan. Jogjakarta: Ar-Ruzz Media

Basuki, Sukur. 2014. “Harus Proporsional Sesuai Jenis dan Jenjang Sekolah”. (http://www.strkN1lmj.sch.id/?) diakses tanggal 22 September 2018

Djaali. 2008. Psikologi Pendidikan. Jakarta: Bumi Aksara

Gunawan, Heri. 2012. Pendidikan Karakter Konsep Dan Implementasi. Bandung: Alfabeta

Hasan, Nor. 2006. Full Day School (Model Aternatif Pembelajaran Bahasa Asing ). Jurnal Pendidikan. Vol. 1. No. 1. Hal: 109-118

Hilalah, Nur. 2009. Tesis. Pelaksanaan Full Day School Di SD Plus Nurul Hikmah Pamekasan (Telaah Problematika Perkembangan Sosial Peserta Didik). http://iwankuswandi.wordpress.com/2018/09/09/fullday-school-danpendidikanterpadu/http://www.alwanku.com

Indrawan, R. \& Yaniawati R.P. 2014. Metodologi Penelitian Kuantitatif, Kualitatif, dan Campuran Untuk Manajemen, Pembangunan, dan Pendidikan. Bandung: PT. Refika Aditama

Kementerian Pendidikan Nasional, Dirjen Dikti. 2010. Sistem Penjaminan Mutu Perguruan Tinggi (SPM-PT)

Kementrian Pendidikan Nasional. 2011. Panduan Pelaksanaan Pendidikan Karakter. Jakarta: Badan Penelitian dan Pengembangan Pusat Kurikulum dan Perbukuan

Kesuma, Dharma,dkk. 2011. Pendidikan Karakter Kajian Teori dan Praktik diSekolah. Bandung: Remaja Rosdakarya

Kewo, C. L. Pengaruh Penganggaran Partisipatif, Komitmen Organisasi Dan Pengendalian Intern Terhadap Kinerja Manajerial Aparatur Pemerintah Kabupaten Minahasa. Jurnal Riset Akuntansi dan Keuangan, 7(1), $29-42$.

Kewo, C. L., \& Afiah, N. N. (2017). Does Quality of Financial Statement Affected by Internal Control System and Internal Audit? . International Journal of Economics and Financial Issues, 7(2), 568-573.

Muhammad Javed Iqbal. 2009, "Life Long Education: A conceptual Debate", International Journal of media, technology and lifelonglearning Vol.5, N0.2

Mujayanah, Siti. 2016. "Sistem Full Day School Dalam Pembentukan Karakter Siswa Kelas IV SD Muhammadiyah Pakel Yogyakarta”. Tesis. Universitas Islam Negeri. Yogyakarta

Nasution. 2003. Metode Research. Jakarta : PT. Bumi Aksara

Ragella, 2011. "Pengelolaan Pembelajaran Full Day School Di SD Budi Mulia Dua Yogyakarta”. Tesis. Universitas Negeri Yogyakarta: Yogyakarta.

Republik Indonesia, 2003. UU No. 20 Tahun 2003 pasal 1 tentang sistem pendidikan nasional

Republik Indonesia' 2017. Permendikbud No. 23 Tahun 2017 tentang lima hari sekolah

Sedarmayanti. 2011. Manajemen Sumber Daya Manusia, Reformasi Birokrasi dan Manajemen Pegawai Negeri Sipil. Bandung : PT. RefikaAditama

Seli, Muhammad. 2009. "Metode Pembelajaran Pendidikan Agama Islam Dalam Full Day School Di Sekolah Alam Bilingual Madrasah Tsanawiyah Surya Buana Lowokwaru Malang”. Skripsi. Universitas Negeri Malang: Malang.

Setyarini, I. N. (2014). Penerapan Sistem Pembelajaran "Fun \& Full Day School" Untuk Meningkatkan Religiusitas Peserta Didik di SDIT Al Islam Kudus. Jurnal Teknologi Pendidikan dan Pengajaran, 232.

Soapatty, L. \& Suyanto, T. (2014). Pengaruh Sistem Sekolah Sehari Penuh (Full Day School) terhadap Prestasi Akademik Siswa SMP Jati Agung Sidoarjo. Kajian Moral dan Kewarganegaraan, Nomor 2 Volume 2 
Halaman 719-733.

Sugiyono. 2012. Metode Penelitian Kuantitatif Kualitatif dan R\&D. Bandung: Alfabeta

Susianti, Purnama \& Asyhar,Ali.2015.” Pelaksanaan Full Day School Sekolah Dasar Islam Terpadu Al Huda Kecamatan Sangkapura Kabupaten Gresik (Studi Problematika Perkembangan Sosial Peserta Didik)”.vol 1.no 1.hal 3.

Zubaedi. 2012. Desain Pendidikan Karakter. Jakarta: Kencana 